Cahiers de recherches médiévales

\title{
Heldris de Cornuälle, Le roman de silence
}

Silvère Menegaldo et Danièle James-Raoul

\section{OpenEdition}

Journals

Édition électronique

URL : https://journals.openedition.org/crm/2302

DOI : $10.4000 / \mathrm{crm} .2302$

ISSN : $1955-2424$

Éditeur

Honoré Champion

\section{Édition imprimée}

Date de publication : 30 décembre 2005

Pagination : 207-210

ISSN : 1272-9752

Référence électronique

Silvère Menegaldo et Danièle James-Raoul, « Heldris de Cornuälle, Le roman de silence », Cahiers de recherches médiévales [En ligne], 12 | 2005, mis en ligne le 30 décembre 2008, consulté le 15 décembre 2022. URL : http://journals.openedition.org/crm/2302 ; DOI : https://doi.org/10.4000/crm.2302

Ce document a été généré automatiquement le 15 décembre 2022.

Tous droits réservés 


\title{
Heldris de Cornuälle, Le roman de silence
}

\author{
Silvère Menegaldo et Danièle James-Raoul
}

1 Tardivement redécouvert (en 1927), plus tardivement édité encore (pour la première fois en 1972), et donc longtemps oublié, Le Roman de Silence d'Heldris de Cornuälle - un auteur par ailleurs inconnu - ne l'est plus aujourd'hui, étant depuis les vingt dernières années l'objet d'un intérêt toujours plus vif de la part de la critique, d'ailleurs surtout anglo-saxonne. Curieuse histoire, de fait, que celle de cette jeune fille contrainte de se déguiser et de vivre comme un homme, parcourant sous divers costumes d'emprunt l'Angleterre et la France, avant de rencontrer Merlin pour qu'il remette bon ordre à sa vie aventureuse - curieuse histoire, qui nous donne non seulement une œuvre singulière, mais aussi un des très beaux romans que nous ait légués le XIII ${ }^{e}$ siècle. Aussi avons-nous voulu consacrer ce premier « Regard sur une œuvre » à ce Roman de Silence encore trop méconnu, du moins en France. Danièle James-Raoul en prépare actuellement une nouvelle édition, qui devra bientôt paraître dans les Classiques Français du Moyen Âge des éditions Champion, et notre petit dossier aura donc effet d'annonce; précisons en outre qu'il sera complété dans la prochaine livraison des Cahiers de Recherches Médiévales par un article de Regina Psaki (University of Oregon) consacré à la réception du roman par la critique anglo-saxonne. (S. M.)

\section{BIBLIOGRAPHIE}

ÉDITIONS ET TRADUCTIONS

Le Roman de Silence. A thirteenth-century Arthurian verse-romance by Heldris de Cornuälle, éd. L. Thorpe, Cambridge, W. Heffer, 1972. 
Le Roman de Silence, trad. R. Psaki, New York, Garland, 1991.

Silence. A thirteenth-century french romance, éd. et trad. S. Roche-Mahdi, East Lansing (Michigan), Colleagues Press, 1992.

Le Roman de Silence, trad. F. Bouchet, Récits d'amour et de chevalerie, éd. D. Régnier-Bohler, Paris, Laffont, 2000, p. 459-557.

Il romanzo di Silence, éd. et trad. A. Airò, Rome, Carocci, 2005.

ÉTUDES

Arthuriana. Special Issue on Le Roman de Silence, éd. R. Psaki, Dallas, Southern Methodist University, 7, 2, 1997 [7 articles de L. Kochanske Stock, E. A. Waters, K. M. Blumreich, E. F. Labbie, R. Psaki, C. Jewers et G. Thomas Gilmore].

Arthuriana. Special Issue : Essays on Le Roman de Silence, éd. R. Psaki, Dallas, Southern Methodist University, 12, 1, 2002 [11 articles de S. Roche-Mahdi, L. Kochanske Stock, R. S. Sturges, R. L. A. Clark, S. Kinoshita, R. Omar Khan, K. M. Krause, K. Blumreich, M. Bolduc, L. Dahmen et C. Callahan].

AKBARI S. CONKLIN, « Nature's Forge Recast in the Roman de Silence ", Literary Aspects of Courtly Culture, éd. D. Maddox et S. Sturm-Maddox, Cambridge, Brewer, 1994, p. 39-46.

ALLEN P. L., " The Ambiguity of Silence. Gender, Writing, and Le Roman de Silence ", Sign, Sentence, Discourse. Language in Medieval Thought and Literature, éd. J. N. Wasserman et L. Roney, Syracuse University Press, 1989, p. 98-112.

BIBBEE, Evan J., Reticent Romans : Silence and Writing in La Vie de Saint Alexis, Le Conte du Graal and Le Roman de Silence, Ph. D., Louisiana State University, 2003.

BLOCH R.H., « Silence and Holes : The Roman de Silence and the Art of the Trouvère ", Yale French Studies, 70, 1986, p. 81-99.

BOLDUC M., "Silence's Beasts ", The Mark of the Beast. The Medieval Bestiary in Art, Life, and Literature, éd. D. Hassig, New York, Garland, 1999, p. 185-209.

BOUCHET F., «L'écriture androgyne : le travestissement dans Le Roman de Silence », Le Nu et le vêtu au Moyen Âge (XII ${ }^{e}$-XIII ${ }^{e}$ siècles), Senefiance, 47, 2001, p. 47-58.

BRAHNEY K.J., " When Silence was Golden : Female Personae in the Roman de Silence », The Spirit of the Court, éd. G. S. Burgess et R. A. Taylor, Cambridge, Brewer, 1985, p. 52-61.

CALLAHAN C., "Canon Law, Primogeniture, and the Marriage of Ebain and Silence », Romance Quarterly, 49, 2002, p. 12-20.

CLEMENTS P., « Shape-Shifting and Gender-Bending : Merlin's Last Laugh at Silence », The Future of the Middle Ages and the Renaissance : Problems, Trends, and Opportunities for Research, éd. R. Dahood, Turnhout, Brepols, 1998, p. 43-51.

CONNOCHIE-BOURGNE C., «L'ascension de la 'pucele vasletee' dans Le Roman de Silence d'Heldris de Cornouaille », Reines et princesses au Moyen Âge, Cahiers du CRISIMA, 5, 2001, p. 795-807.

COOPER K. MASON, «Elle and L: Sexualized Textuality in Le Roman de Silence », Romance Notes, 25, 1985, p. 341-360.

DAHMEN L. M., The Roman de Silence and the Narrative Traditions of the Thirteenth-Century, Ph. D., Indiana University, 2000. 
FRAPPIER J., "Le Roman de Silence », dans Grundriss der romanischen Literaturen des Mittelalters IV / 1. Le Roman jusqu'à la fin du XIII ${ }^{e}$ siècle, éd. J. Frappier et R.R. Grimm, Heidelberg, Carl Winter, 1978, p. 467-474.

GALLAGHER E. J., " The Modernity of Le Roman de Silence ", University of Dayton Review, 21, 3, 1992, p. 31-42.

GAUNT S., « The significance of Silence », Paragraph, 13, 1990, p. 202-216.

GELZER H., « Der Silenceroman von Heldris de Cornualle », Zeitschrift für romanische Philologie, 47, 1927, p. 87-99.

- Nature : zum Einfluss des Scholastik auf den französischen Roman, Halle, Niemeyer, 1917.

GÖRING W., Untersuchung der Sprache des Roman de Silence von Heldris de Cornuälle, Halle, Klinz, 1930.

JAMES-RAOUL D., « Un curieux avatar de L'Estoire Merlin : Le Roman de Silence », Traduction, transposition, adaptation au Moyen Âge, Bien dire et bien aprandre, 13, 1996, p. 145-157.

- La Parole empêchée dans la littérature arthurienne, Paris, Champion, 1997.

KEENE K., «"Cherchez Eufeme" : the Evil Queen in Le Roman de Silence », Arthuriana, 14, 3, 2004, p. 3-22.

KINOSHITA S., « Heldris de Cornuälle's Roman de Silence and the Feudal Politics of Lineage », Publications of the Modern Language Association of America, 110, 1995, p. 397-409.

KOCHER S., « Undermining Oppositionality : The Romance of Silence's Nature / Nurture Debate Complicated by the Rhymes of apelier (to name) and celer (to conceal) », Romance Languages Annual, 7, 1995, p. 95-99.

- « Narrative Structure of the Roman de Silence : Lessons in Interpretation », Romance Notes, 42, 2002, p. 349-358.

KRUEGER R. L., Women Readers and the Ideology of Gender in Old French Verse Romance, Cambridge University, 1993, p. 101-127.

LABBIE, E. F., Challenging Chivalric Assumptions and the "Law of Sex»: Gender and Identity in Le Roman de Silence, Gabriel and The Female Quixote, Ph.D., Brucknell University, 1995.

LASRY A. BENAIM, « The Ideal Heroine in Medieval Romances : A Quest for a Paradigm », Kentucky Romance Quarterly, 32, 3, 1985, p. 227-243

LECOY F., « Corrections : Le Roman de Silence d'Heldris de Cornualle », Romania, 99, 1978, p. 109-125.

LLOYD H., "The Triumph of Pragmatism : Reward and Punishment in Le Roman de Silence ", Rewards and Punishments in the Arthurian Romances and Lyric Poetry of Medieval France. Essays Presented to Kenneth Varty, éd. P.V. Davies et A.J. Kennedy, Cambridge, Brewer, 1987, p. 77-88.

MAC CRACKEN P., « 'The Boy Who Was a Girl'. Rending Gender in the Roman de Silence », Romanic Review, 85, 1994, p. 515-534.

- The Romance of Adultery. Queenship and Sexual Transgression in Old French Literature, University of Pennsylvania, 1998.

PERRET M., « Travesties et transsexuelles : Yde, Silence, Grisandole, Blanchandine ", Romance Notes, 25, 1985, p. 328-340.

PRATT K., « Humour in the Roman de Silence », Arthurian Literature XIX : Comedy in Arthurian Literature, éd. K. Busby et R. Dalrymple, Cambridge, Brewer, 2003, p. 87-103. 
RINGER L., « Exchange, Identity and Transvestism in Le Roman de Silence », Dalhousie French Studies, 28, 1994, p. 3-13.

STOCK L. KOCHANSKE, «Arms and the (Wo)man in Medieval Romance : The Gendered Arming of Female Warriors in the Eneas and Heldris's Roman de Silence ", Arthuriana, 5, 4, 1995, p. 56-83.

TRACHSLER R., Disjointures-Conjointures. Étude sur l'interférence des matières narratives dans la littérature française du Moyen Âge, Tübingen-Bâle, Francke, 2000, p. 118-126.

VICTORIN P., «Le nu et le vêtu dans Le Roman de Silence : métaphore de l'opposition entre nature et norreture ", Le Nu et le vêtu au Moyen Âge (XII'-XIII siècles), Senefiance, 47, 2001, p. 365-382.

WHITE, C. L., « Not so Dutiful Daughters : Women and their Fathers in three French Medieval Works : Le Roman de Silence, Erec et Enide and Le Livre de la Cité des dames ", Cincinnati Romance Review, 18, 1999, p. 189-199.

WILLIAMS G. S., « Konstruierte Männlichkeit. Genealogie, Geschlecht und ein Briefwechsel in Heldris von Cornwalls Roman de Silence », Gespräche, Boten, Briefe. Körpergedächtnis und Schriftgedächtnis im Mittelalter, éd. H. Wenzel, Berlin, Schmidt, 1997, p. 193-211.

\section{AUTEURS}

\section{SILVÈRE MENEGALDO}

Université d'Orléans

DANIÈLE JAMES-RAOUL

Université Paris-IV Sorbonne 